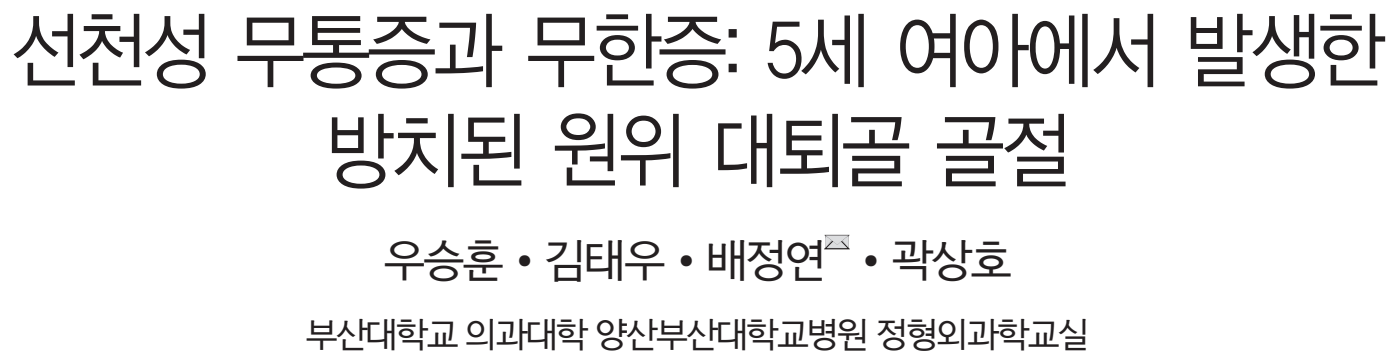

\title{
Congenital Insensitivity to Pain with Anhidrosis: Five-Year-Old Girl with a Neglected Distal Femur Fracture
}

\author{
Seung Hun Woo, M.D., Tae Woo Kim, M.D., Jung Yun Bae, M.D. ${ }^{\llbracket}$, and Sang Ho Kwak, M.D. \\ Department of Orthopedic Surgery, Pusan National University Yangsan Hospital, Pusan National University School of Medicine, Yangsan, Korea
}

Congenital insensitivity to pain with anhidrosis (CIPA) is a rare disease that affects the sensory and autonomic nervous system. The patients do not have the ability to sense different sensations, such as pain, which tends to lead to different injuries. In addition, the patients suffer from fluctuations in body temperature due to autonomic involvement. The present case was a five-year-old girl with a neglected distal femur fracture. X-rays taken during the follow-up showed marked callus formation and pseudarthrosis of the distal femur. She had biting injuries of the tongue, auto-amputation of the fingers, some developmental delay and a history of recurrent fever with an unknown origin. The electrodiagnostic study was normal. The quantitative sudomotor axon reflex test revealed markedly reduced postganglionic sudomotor axonal responses at all sites recorded on the left. She was diagnosed with CIPA. As the initial presentation of CIPA involves the musculoskeletal system, orthopedic surgeons should have a high index of suspicion.

Key words: femur, hereditary sensory and autonomic neuropathy type IV, congenital insensitivity to pain with anhidrosis

선천성 무통증과 무한증(congenital insensitivity to pain with anhidrosis, CIPA)은 매우 드문 유전성 질환으로 제4형 유전성 감각자 율신경병증(hereditary sensory and autonomic neuropathy, HSAN $\mathrm{IV})$ 이라고도 불리며 통각과 온각이 소실되고 발한 기능이 없거나 감소되는 질환이다.1) 영아기부터 시작되는 불명열을 비롯한 다양 한 전신적인 증상을 보이며 정형외과적으로 보았을 때 수지 말단 부 절단, 신경병성 관절증, 변형이나 가관절증을 동반하기도 하는 재발성 골절, 무혈성 괴사, 골수염, 화농성 관절염 등의 증상을 보 인다.') 저자들은 수상 시기를 알 수 없는 우측 원위 대퇴골 골절

Received September 11, 2018 Revised January 13, 2019

Accepted February 24, 2019

Correspondence to: Jung Yun Bae, M.D.

Department of Orthopedic Surgery, Pusan National University Yangsan Hospital, 20

Geumo-ro, Mulgeum-eup, Yangsan 50612, Korea

TEL: +82-55-360-2125 FAX:+82-55-360-2155 E-mail: nari1006@gmail.com

ORCID: https://orcid.org/0000-0001-8026-9330
로 내원한 환자를 치료하는 과정 중에 CIPA로 진단하였고, 그 경 험을 문헌 고찰과 함께 보고하는 바이다.

$$
\text { 증례보고 }
$$

5세 여자 환아가 수상 시기를 알 수 없는 우측 원위 대퇴골 골절 을 주소로 내원하였다. 내원 2주 전 인근 병원을 방문하여 시행한 방사선 소견상 전위가 거의 없는 Salter-Harris 제 2 형 골절 소견을 보였고(Fig. 1) 주위로 가골이 형성되기 시작한 것으로 보아 수상 후 어느 정도 시간이 지난 것으로 추정되었다. 그런데 1-2개월의 추시 기간 중 가골이 과도하게 형성되고(Fig. 2), 무릎 주위로 열 감과 부종, 삼출액 소견이 관찰되어 골수염, 악성 종양 등과의 감 별을 위해 혈액검사, 관절 천자 및 자기공명영상(magnetic resonance imaging, MRI)을 시행하였다. 혈액검사나 관절 천자 검사상 감염을 의심할 만한 소견은 없었다. MRI상 골수강 내는 잘 보존된 

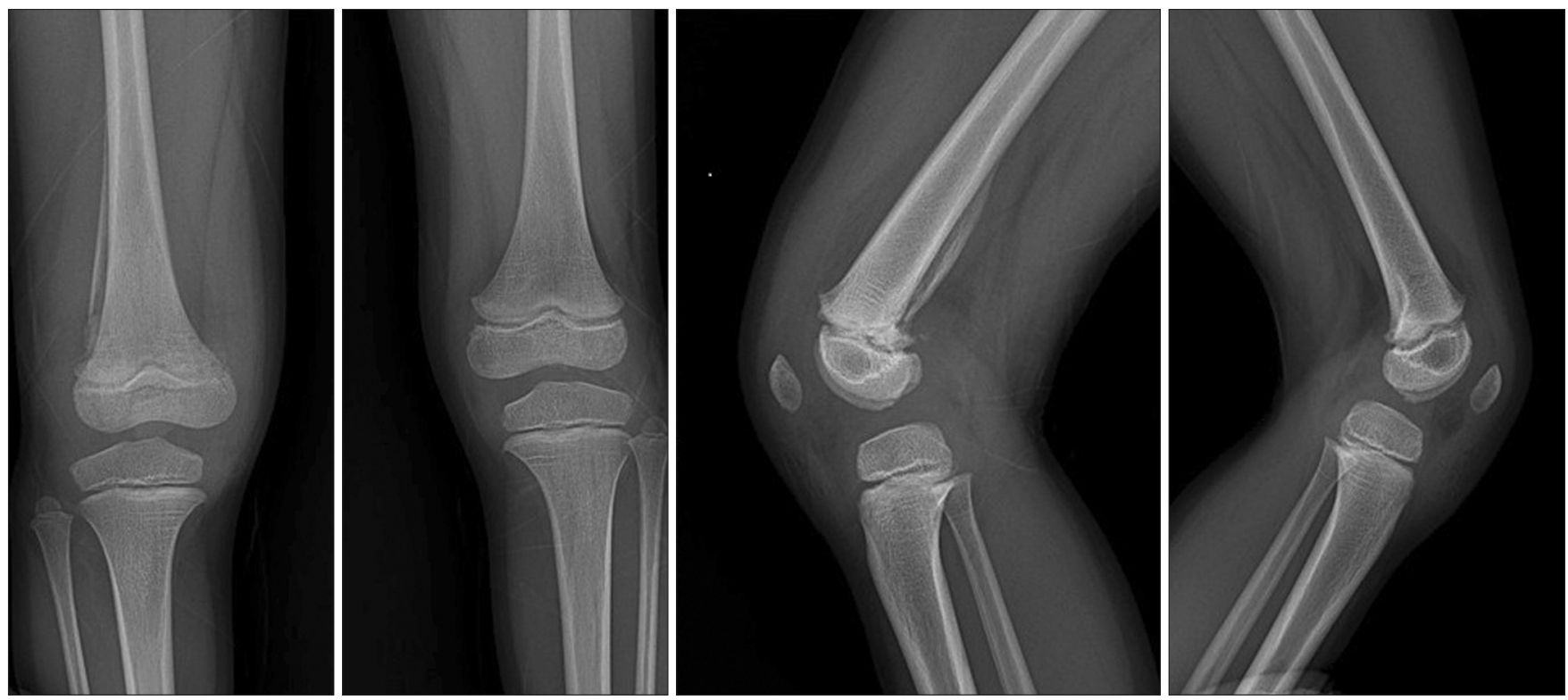

Figure 1. Radiographs of the right knee joint obtained at the first visit in another clinic show a fracture of the distal femur.
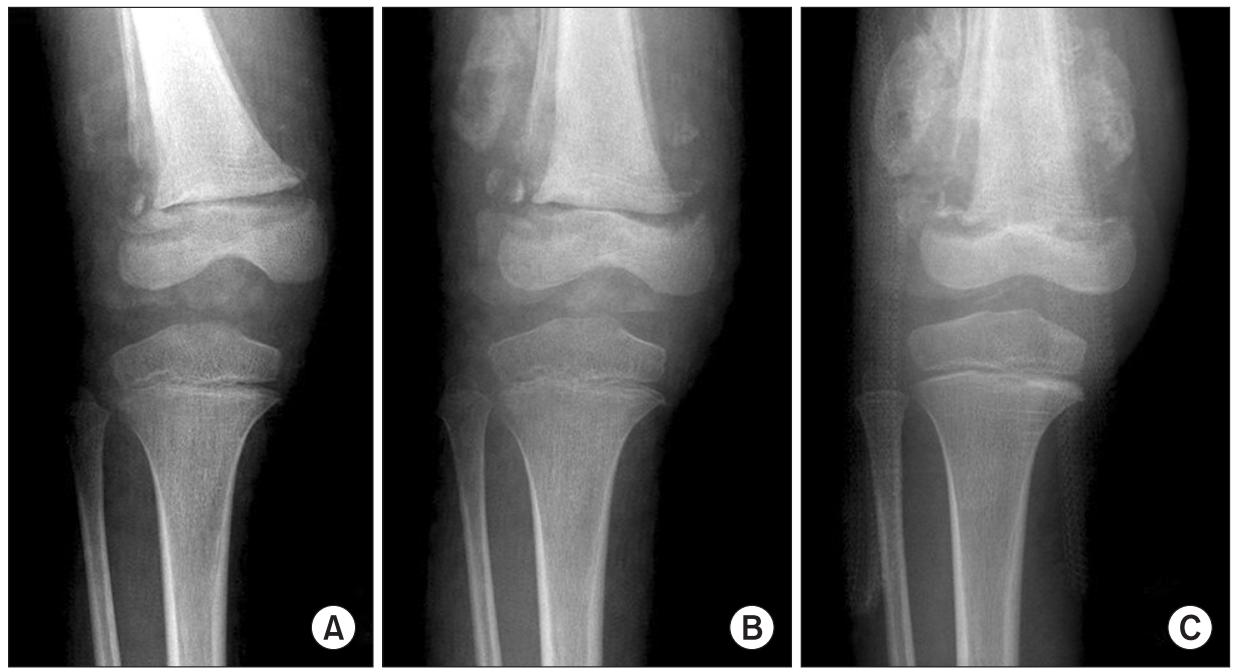

Figure 2. Radiographs taken during the follow-up shows marked callus formation and pseudarthrosis of the distal femur epiphysis. (A) Radiograph at the initial visit. (B) Radiograph taken three weeks later. (C) Radiograph taken seven weeks later.

상태로 주로 광범위한 신생골 형성 소견 및 골간단에 피질골의 파괴 및 가관절 소견을 보였다(Fig. 3). 단순 방사선 추시상에서도 시간이 경과함에 따라 가골 형성이 감소하고 주위 조직과 경계가 명확해지며 골유합 소견이 보이기 시작하여 악성 종양이나 감염 을 배제하였다. 장하지 석고 고정을 하며 치료하였음에도 골절부 주위로 과도한 가골 및 가관절이 발생한 것이 이상하여 다시 과 거 병력 청취 및 우측 하지 이외의 부분에 대해 이학적 검사를 시 행하였다. 출생 직후부터 불명열이 많았고, 평소 통증에 둔감하였 다. 혀와 손끝에 상처가 많았고 말단에 절단 소견이 관찰되었다 (Fig. 4, 5). 근전도/신경전도 검사에서는 이상 소견이 관찰되지 않 았고, 정량적 발한 축삭 반사검사에서는 한선의 분비 기능이 거 의 없었다. 유전자 검사상 neurotrophic receptor tyrosine kinase 1
(NTRK1) 유전자에 대한 변이를 찾아내지 못해 확진하지는 못했 으나 동통 불감증, 출생 직후부터 반복적인 불명열, 땀을 흘리지 않는 점, 수지 말단부 절단 및 구강 내 흥터, 원위 대퇴골과 원위 경골에 비후성 불유합 소견을 바탕으로 CIPA로 진단하였으며 기 술적 방치하였고, 10개월 추시만에 유합을 얻었다(Fig. 6).

\section{고 찰}

$\mathrm{HSAN}$ 은 감각신경과 자율신경을 침범하는 임상적, 유전학적으 로 이질적인 선천성 말초신경질환군으로서 원인유전자와 임상 증상을 바탕으로 8형으로 분류되고 있다(Table 1). ${ }^{3-6)} \mathrm{HSAN} \mathrm{IV}$ 인 CIPA는 1963년 처음으로 소개된 상염색체 열성 유전하는 드 

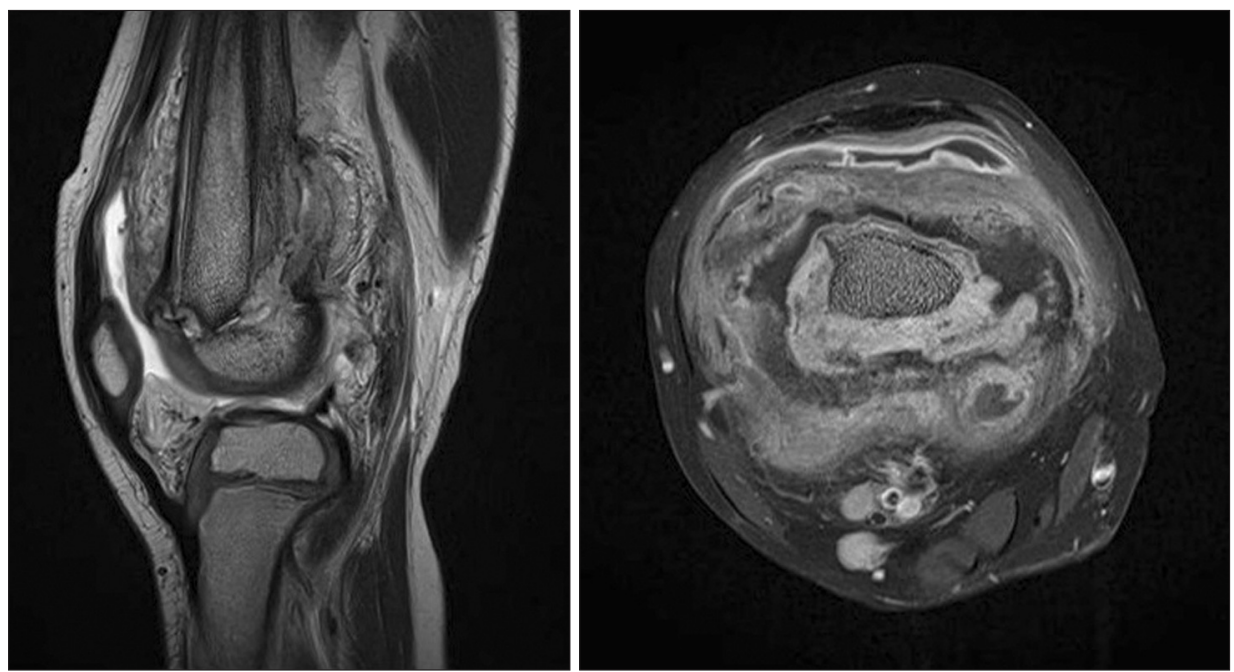

Figure 3. Magnetic resonance imagings revealing the pericortical area surrounding with the distal femur shaft considered to be ossification or marked new bone formation, relatively normally preserved bone marrow of the distal femur.
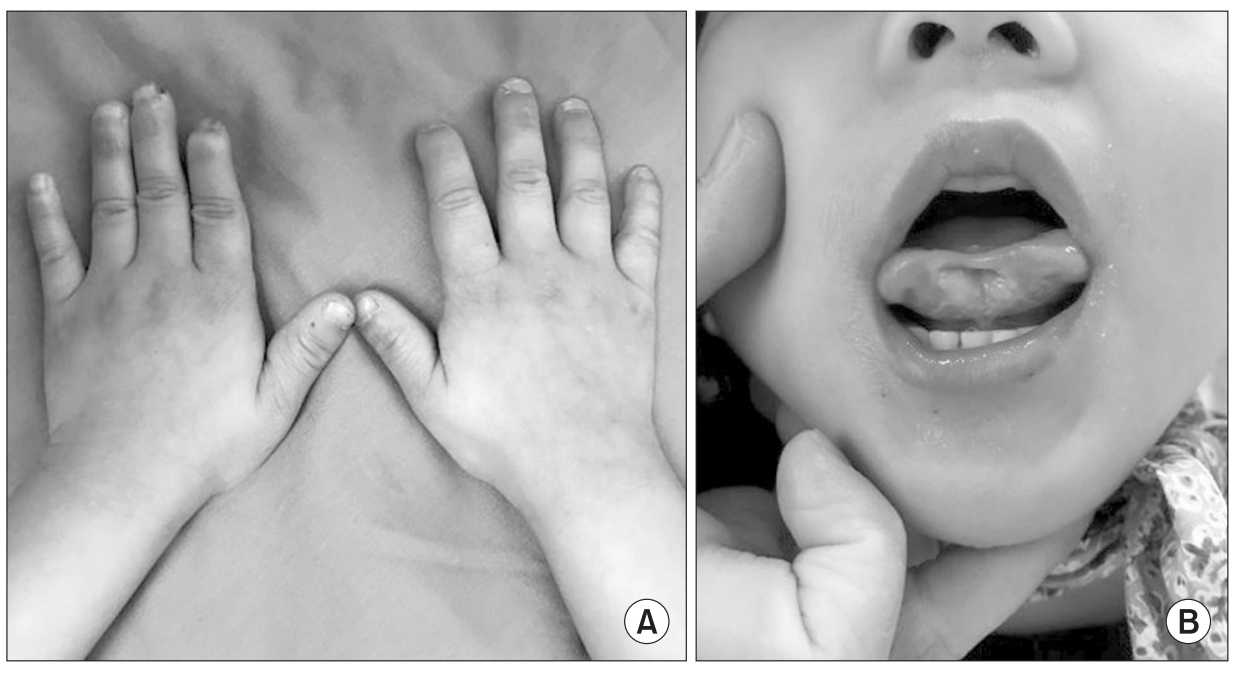

Figure 4. Pictures showing the clinical features of the patient. (A) Post traumatic deformity and missing terminal part of the fingers. (B) Biting injuries of the tongue and multiple healed scars in the oral cavity.
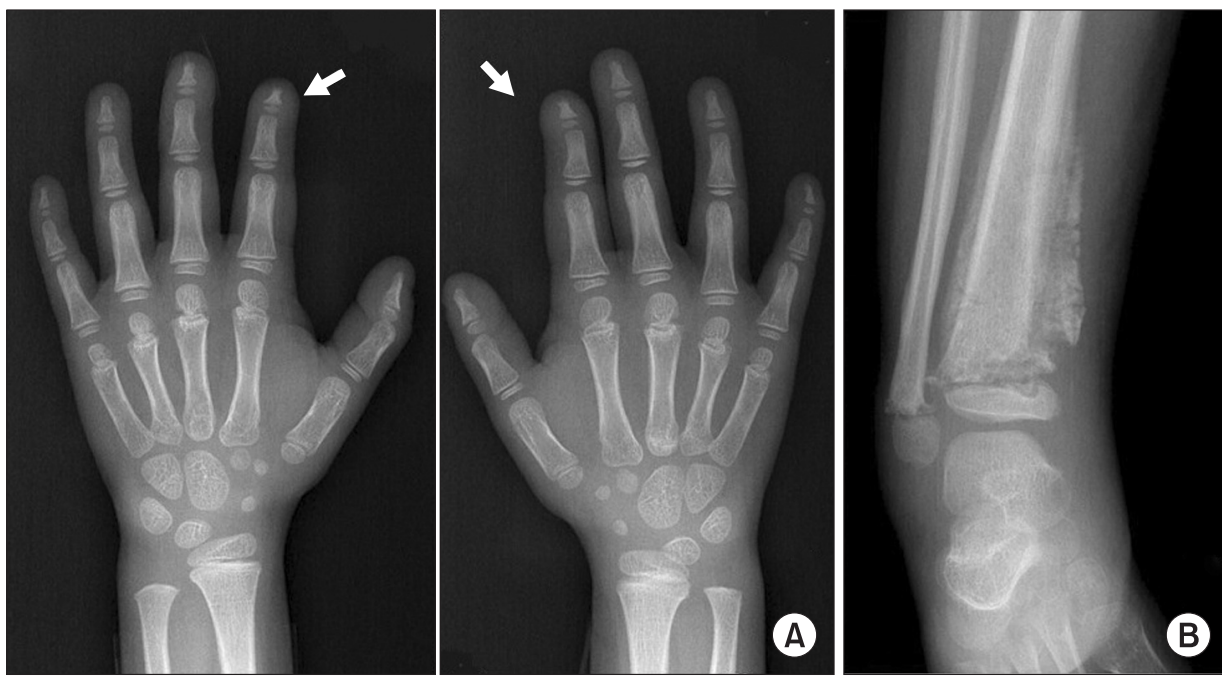

Figure 5. Radiographs of the hands and right distal femur. (A) Both hands show a missing terminal phalanx of the index finger (arrows). (B) Radiograph reveal nonunion with exuberant callus at the right distal tibia. 

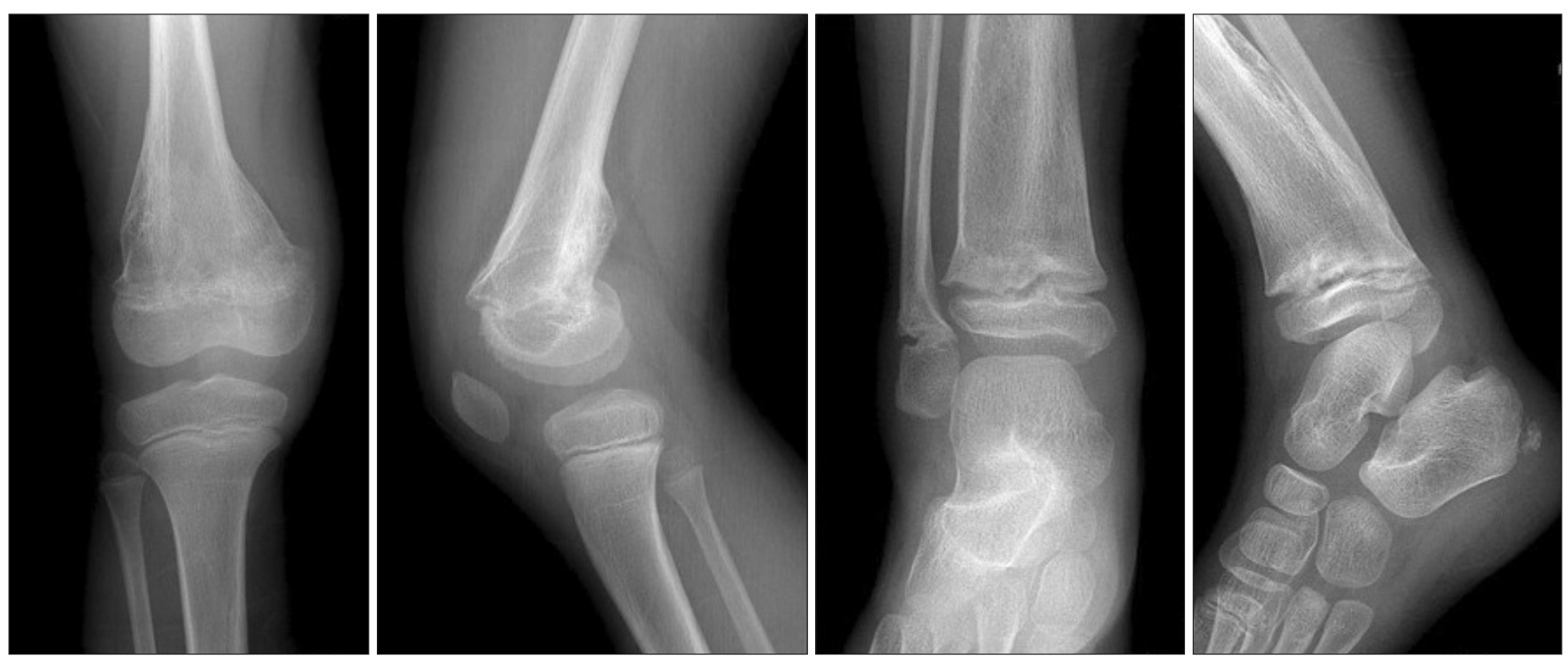

Figure 6. Final follow-up X-rays show complete healing of the right distal femur and distal tibia fractures.

Table 1. Overview of the HSAN Types with the Corresponding Gene, Inheritance Pattern, and Clinical Features

\begin{tabular}{|c|c|c|c|}
\hline Type & Gene & Inheritance & Clinical features \\
\hline HSAN1 & $\begin{array}{l}\text { SPTLC1 } \\
\text { SPTLC2 } \\
\text { ATL1 } \\
\text { DNMT1 } \\
\text { ATL3 }\end{array}$ & $A D$ & $\begin{array}{l}\text { Onset often in early adulthood but variable, distal sensory loss, foot ulcers, } \\
\text { preservation of facial sensation, variable muscle wasting and weakness, } \\
\text { variable neural deafness and dementia }\end{array}$ \\
\hline $\begin{array}{l}\text { HSAN2 (congenital } \\
\text { sensory neuropathy) }\end{array}$ & $\begin{array}{l}\text { WNK1/HSN2 } \\
\text { FAM134B } \\
\text { KIF1A }\end{array}$ & AR & $\begin{array}{l}\text { Loss of pain, temperature and tactile sensation, recurrent infection and } \\
\text { fractures of the digits }\end{array}$ \\
\hline $\begin{array}{l}\text { HSAN3 (familial } \\
\text { dysautonomia) }\end{array}$ & IKBKAP & AR & $\begin{array}{l}\text { Progressive sensorimotor neuropathy, sympathetic autonomic dysfunction, } \\
\text { smooth tongue without fungiform papillae, excessive sweating }\end{array}$ \\
\hline $\begin{array}{l}\text { HSAN4 (congenital } \\
\text { insensitivity to pain } \\
\text { with anhidrosis) }\end{array}$ & NTRK1 & AR & $\begin{array}{l}\text { Loss of pain sensitivity, defects in thermoregulation, anhidrosis, mild to } \\
\text { moderate mental retardation, microcephaly }\end{array}$ \\
\hline HSAN5 & NGFB & AR & $\begin{array}{l}\text { Loss of pain and temperature sensation, normal muscle strength, reflexes, } \\
\text { nerve conduction, painless fractures, joint deformities, normal intelligence }\end{array}$ \\
\hline HSAN6 & DST & AR; Ashkenazi Jewish & $\begin{array}{l}\text { Neonatal hypotonia, respiratory and feeding difficulties, lack of } \\
\text { psychomotor development, and autonomic abnormalities, death by } \\
\text { age } 2 \text { years }\end{array}$ \\
\hline HSAN7 & SCN11A & $A D$ & $\begin{array}{l}\text { Loss of pain sensitivity, self-mutilation, slow wound healing, painless bone } \\
\text { fractures, gastrointestinal dysfunction, hyperhidrosis }\end{array}$ \\
\hline HSAN8 & PRDM12 & AR & $\begin{array}{l}\text { Loss of pain sensitivity, ulceration to the fingers, tongue, lips, and other } \\
\text { distal appendages, decreased sweating and tear production }\end{array}$ \\
\hline
\end{tabular}

HSAN, hereditary sensory and autonomic neuropathy; AD, autosomal dominant; AR, autosomal recessive.

문 질환으로 신경성장인자(nerve growth factor, NGF)의 수용체 인 NTRK1 유전자의 변이로 인해 발생하며 다른 중추 및 말초신 경계의 이상 없이 통증에 대한 주관적, 객관적 반응이 없고, 발한 기능이 저하되어 있다. ${ }^{7-9)}$ 이러한 특징 때문에 환아는 영아기부
터 시작되는 원인을 알 수 없는 반복된 고열, 수지 말단부의 상처 및 절단, 혀나 입술, 치아 등에 반복적인 상처와 흥터, 각막 손상 소견과 더불어 정형외과적인 증상도 많이 동반되는데 과다한 신 생골 형성을 동반한 다발성 골절, 신경병성 관절증, 하지 부동, 골 
수염 및 화농성 관절염, 고관절 탈구, 진행성 척추측만증 등이 있 다. ${ }^{27)}$ 감별해야 할 질환으로는 통각이나 온각이 저하되는 특징을 갖는 CIPA를 제외한 HSAN 질환군들,-6) hypoxanthine-guanine phosphoribosyltransferase (HPRT)의 결핍으로 퓨린 합성에 선천 적 이상이 생기는 Lesch-Nyhan 증후군,10) 한센병' 등이 있다. 치 료 시 환자의 협조가 잘 이루어지지 않기 때문에 감염이나 내고 정물 파손, 불유합, 지연 유합 등의 발생 빈도가 매우 높고, 석고 고정이나 보조기를 이용한 치료 역시 욕창이 발생하는 등 치료가 어렵다. ${ }^{2)}$ 화농성 관절염이나 골수염에서는 적극적인 배농 절개술 이 필요하지만 그 이외의 경우에서는 기술적인 방치를 시행하는 것이 더 이로울 수 있다. CIPA는 매우 드문 질환이고 감각자율신 경계 질환이기 때문에 정형외과 의사가 CIPA 환자를 만날 확률 은 매우 낮지만 본 증례와 같이 CIPA를 처음으로 진단하는 의사 가 정형외과 의사가 될 수도 있으므로 그 가능성을 염두에 두는 편이 좋겠다.

\section{CONFLICTS OF INTEREST}

The authors have nothing to disclose.

\section{REFERENCES}

1. Freeman R. Autonomic peripheral neuropathy. Lancet. 2005;365:1259-70.

2. Bar-On E, Weigl D, Parvari R, Katz K, Weitz R, Steinberg T. Congenital insensitivity to pain. Orthopaedic manifestations. J Bone Joint Surg Br. 2002;84:252-7.
3. Rotthier A, Baets J, De Vriendt E, et al. Genes for hereditary sensory and autonomic neuropathies: a genotype-phenotype correlation. Brain. 2009;132:2699-711.

4. Edvardson S, Cinnamon Y, Jalas C, et al. Hereditary sensory autonomic neuropathy caused by a mutation in dystonin. Ann Neurol. 2012;71:569-72.

5. Leipold E, Liebmann L, Korenke GC, et al. A de novo gainof-function mutation in SCN11A causes loss of pain perception. Nat Genet. 2013;45:1399-404.

6. Chen YC, Auer-Grumbach M, Matsukawa S, et al. Transcriptional regulator PRDM12 is essential for human pain perception. Nat Genet. 2015;47:803-8.

7. Swanson AG. Congenital insensitivity to pain with anhydrosis. A unique syndrome in two male siblings. Arch Neurol. 1963;8:299-306.

8. Indo Y, Tsuruta M, Hayashida Y, et al. Mutations in the TRKA/NGF receptor gene in patients with congenital insensitivity to pain with anhidrosis. Nat Genet. 1996;13:485-8.

9. Indo Y. Genetics of congenital insensitivity to pain with anhidrosis (CIPA) or hereditary sensory and autonomic neuropathy type IV. Clinical, biological and molecular aspects of mutations in TRKA(NTRK1) gene encoding the receptor tyrosine kinase for nerve growth factor. Clin Auton Res. 2002;12 Suppl 1:I20-32.

10. James WD, Berger TG, Elston DM. Andrews' diseases of the skin: clinical dermatology. Philadelphia: Saunders Elsevier; 2006. 546. 


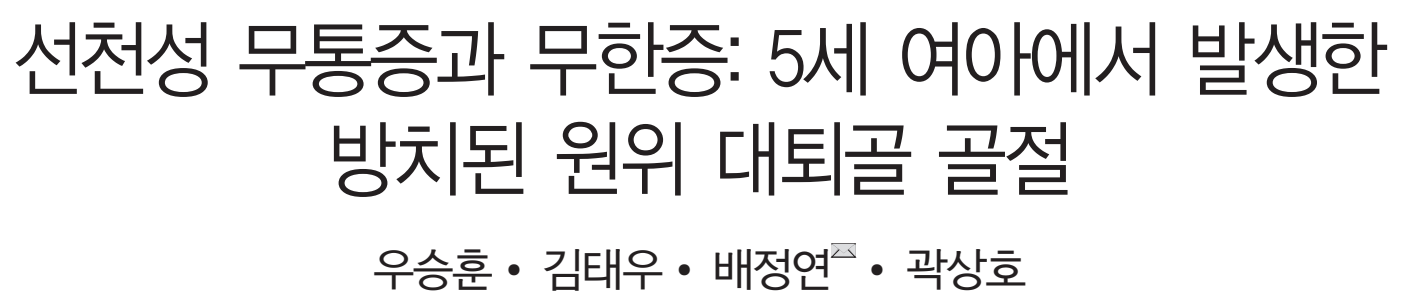

부산대학교 의과대학 양산부산대학교병원 정형외과학교실

선천성 무통증과 무한증(congenital insensitivity to pain with anhidrosis, CIPA)은 감각신경계와 자율신경계가 이환되는 질환으로 상염색체 열성으로 유전되는 드문 질환이다. 우리 환자는 방치된 원위 대퇴골 골절로 내원한 5 세 여아로 추시 도중 시행한 방사선 사 진에서 과도한 가골과 가관절 소견을 보였으며, 손가락의 절단, 반복적인 불명열의 과거력을 갖고 있었다. 근전도/신경전도 검사에서 는 이상 소견이 관찰되지 않았고, 정량적 발한 축삭 반사검사에서는 한선의 분비 기능이 거의 없는 소견을 보여 이를 바탕으로 CIPA 로 진단하였다. 매우 드문 질환이고 감각자율신경계 질환이기 때문에 정형외과 의사가 $\mathrm{CIPA}$ 환자를 만날 확률은 매우 낮지만 본 증 례의 경우처럼 정형외과 의사가 $\mathrm{CPA}$ 를 처음으로 진단하는 의사가 될 수도 있으므로 그 가능성을 염두에 두어야 하겠다.

색인단어: 대퇴골, 제4형 유전성 감각자율신경병증, 선천성 무통증과 무한증

접수일 2018년 9월 11일 수정일 2019년 1월 13일 게재확정일 2019년 2월 24일

책임저자 배정연

50612 양산시 물금읍 금오로 20, 양산부산대학교병원 정형외과

TEL 055-360-2125, FAX 055-360-2155, E-mail nari1006@gmail.com, ORCID https://orcid.org/0000-0001-8026-9330 